\title{
The Case of Being a Teacher at Science and Art Centers: A Phenomenological Quantitative Research *
}

\author{
Mustafa Akda $\breve{g}^{* *} \quad$ Cem Şenol $^{* * *}$
}

\begin{abstract}
The aim of the research is to examine "the case of being a teacher in Science and Art Centers". 13 teachers selected from Science and Art Centers in three different cities in the Eastern Anatolia region of Turkey in the 2015-2016 academic year constitute the study group of this research designed a phenomenological research design of Qualitative research approach. In the selection of the study group the criterion sampling method, one of purposive sampling method use in in phenomenological studies, was used. Semi-structured interview form was used to collect the data. The preliminary application of the interview form was carried out with three teachers working in Science and Art Centers. Interviews were made with teachers in the study group. Content analysis method was used in analysis of research data. In this study, it was concluded that teachers find the system in 2007 (old system) better in general in terms of the evaluation criteria and validity of the selection of teachers for Science and Art Centers, and they cannot adopt the system in 2015 (new system) because it contains subjective evaluation criteria. Teachers are adopting learning approaches based on learning by doing-experiencing, project-based learning, trip-observation, active learning and problembased learning while doing instructional activities. It has been seen that teachers are positive in terms of being teachers in Science and Art Centers, providing personal/professional development and occupational satisfaction, enhancing learningteaching motivation, being prestigious and having a free learning-teaching environment. It has been seen that teachers are negative in terms of being teachers in Science and Art Centers because of long working hours and cannot complete enough additional tuition fees. It was also concluded that teachers communicate with students effectively, while their communication with parents is inadequate. In line with the research results, the following suggestions can be made: the selection of teachers to the Science and Art Centers should be done objectively, work should be done for strengthening the teachers the interaction and co-operation with parents.
\end{abstract}

Keywords: Science and Art Centers, teachers of gifted and talented, gifted education, phenomenology

\footnotetext{
* This study was partly presented at the $8^{\text {th }}$ International Congress of Educational Research in Çanakkale, Turkey, 05-08 May, 2016.

** Assoc. Prof. Dr. Inonu University, Faculty of Education, Department of Educational Sciences, Malatya, Turkey. E-mail: mustafa.akdag@inonu.edu.tr

*** Correspondence Author: PhD. Student, Inonu University, Faculty of Education, Department of Educational Sciences, Malatya, Turkey. E-mail: cem-senol@hotmail.com.tr
} 


\title{
Bilim ve Sanat Merkezlerinde Öğretmen Olma Olgusu: Nitel Bir Fenomenolojik Araştırma
}

\begin{abstract}
$\ddot{O} \mathbf{z}$
Araştırmanın amacı "Bilim ve Sanat Merkezlerinde öğretmen olma" olgusunu incelemektir. Nitel araştırma yaklaşımlarından fenomenolojik desende tasarlanan araştırmanın çalışma grubunu 2015-2016 eğitim-öğretim yılında Türkiye'nin Doğu Anadolu Bölgesindeki üç farklı şehrinde bulunan Bilim ve Sanat Merkezlerinden seçilen 13 öğretmen oluşturmaktadır. Çalışma grubunun seçiminde, fenomenolojik araştırmalarda kullanılan amaçlı örnekleme yöntemlerinden biri olan ölçüt örnekleme yöntemi kullanılmıştır. Verileri toplamak amacıyla yarı yapılandırılmış görüşme formu kullanılmıştır. Görüşme formunun ön uygulaması Bilim ve Sanat Merkezlerinde görev yapan üç öğretmen ile gerçekleştirilmiştir. Görüşme formunda, ön uygulama sonuçları ve uzman kişilerin görüşleri doğrultusunda gerekli düzenlemeler yapılmıştır. Çalışma grubundaki öğretmenlerle derinlemesine mülakatlarda bulunulmuştur. Araştırma verileri, içerik analizi yöntemiyle analiz edilmiştir. Araştırmada öğretmenlerin Bilim ve Sanat Merkezlerine öğretmen seçimine ilişkin 2007'deki sistemi değerlendirme kriterleri ve geçerliliği itibariyle daha iyi buldukları, 2015'teki sistemi ise subjektif değerlendirme kriterleri içermesi nedeniyle benimseyemedikleri ortaya çıkmıştır. Öğretmenlerin, yaparak yaşayarak öğrenme, proje temelli öğrenme, gezi-gözlem, aktif öğrenme ve probleme dayalı öğrenme kapsamında öğretimsel faaliyetlerini gerçekleştirdikleri belirlenmiştir. Öğretmenlerin, Bilim ve Sanat Merkezlerinde öğretmen olmayı, kişisel/mesleki gelişime ve mesleki doyuma katkı sağlaması, öğrenme-öğretme motivasyonunu artırmas1, prestijli olması, özgür öğrenme-öğretme ortamının bulunması yönleriyle olumlu olarak nitelendirdikleri görülmüştür. Öğretmenler, mesainin uzun olmasını, ek derslerin tamamlanamamasını Bilim ve Sanat Merkezlerinde öğretmen olmanın olumsuz yönleri olarak nitelendirdikleri görülmüştür. Ayrıca öğretmenlerin öğrencilerle etkili iletişim içerisinde oldukları, velilerle kurulan iletişimlerinin ise yetersiz olduğu sonuçlarına ulaşılmıştır. Araştırma sonuçları doğrultusunda Bilim ve Sanat Merkezlerine öğretmen seçimi, objektif olarak yapılmalıdır, öğretmenlerin velilerle olan işbirliğini ve etkileşimini güçlendirecek çalısmalar yapılmalıdır gibi önerilerde bulunulmuştur.
\end{abstract}

Anahtar Sözcükler: Bilim ve sanat merkezi, üstün yeteneklilerin öğretmenleri, üstün yetenekliler eğitimi, fenomenoloji 


\section{Introduction}

For a society, reaching the level of contemporary civilization by increasing the level of development requires its members using their brain power effectively, revealing their potential and directs it correctly. For this reason, by discovering the society's qualified labor force and using it with an effective education to increase the economic level is an important issue (Summak \& Çelik-Şahin, 2014). Qualified labor force is closely related to improving the ability of gifted children's, constituting a small portion of the population in the country, and using their capacities at the highest level. Gifted individuals can be trained effectively, through the recognition of the individual's capabilities and improving it in a systematic and programmatic way (Gökdere, 2004). With the help of programs enriched with methods and techniques that allows gifted students and to be active with first-hand experiences, their educational requirements can be met (Hebert \& Neumeister, 2000; Sak, 2011). Many countries have given importance to this issue and did studies on it earlier, and they have developed a variety of projects and models for the education of gifted individuals. Although the studies on gifted education in developed countries have reached a good point, its importance has just been recognized in Turkey (Ataman, 1998; Levent, 2011). While the activities related with developing ability for gifted children has a long history in some countries, in our country; the issues such as what are the educational needs of gifted children, what kind of arrangements should be made for them, and environments suitable for the other children might not be enough for these children, are neglected and being quite late for working on them. However, gifted students education undoubtedly is of great importance in terms of the present and future of our country. Based on the principle of equality in education, contributing to the education of gifted children, identifying, developing, directing their superior capabilities, and meet the needs of these individuals, will be for the benefit of humanity and our country (MNE, 2010a; MNE, 2013). In this regard, it is necessary to provide support for gifted students, poised to become the leaders and scientists of the future, with the centers equipped with better facilities. In fact, what these children need is a successful education system which will help them move forward, and guarantee their future (Summak \& Çelik-Şahin, 2014). Considering the gifted individuals' roles in the future, undertaken an active role in this context, the Science and Art Centers (SACs) can be said to carry a great responsibility.

At SACs, the system is based on diagnosing the students' talent and creativity in the early stages, developing and assessing their cognitive, affective and psychomotor skills as a whole (Sicak \& Akkaş, 2013). Students studying at SACs receive project-based education in accordance with their interests and talents beside their formal education (MNE, 2010b). At SACs, as a teaching model, instead of teacher teach model, students learn in a project set by themselves during which related topic is learnt by applications of their own solutions (Davashgil et al, 2004). At SACs a pre-programmed education is not available. Programs are applied under the guidance of leader teachers and are prepared in accordance with the principles of individual learning. The programs are designed to improve children's creativity, skills to find solutions to problems with different approaches and to provide solutions to potential problems. Through this program, it is aimed to make students acquire advanced knowledge, skills, attitudes and behaviors in any discipline by considering cross disciplinary relationships. In these centers, it is aimed to make students learn by doing during the planning, implementation and evaluation stages; to make them to produce, solve problems, think creatively, communicate with the environment, do scientific research and make inventions under the guidance of advisors (MNE, 2015, article 25). It should also be noted that to achieve these aims, the major responsibility is shared with the structural characteristics of SACs and teachers working in these centers. Accordingly, it is clear that adequate attention should be given to the selection of teachers working in these centers and their professional development in the process to achieve the desired level of education for gifted children. According to the Circular of the Teacher Selection for Science and Art Centers, while choosing teachers those requirements were demanded; having a good registration grades in last three years, to having 60 points from verbal part and having 65 points for quantitative part from the Academic Post Graduate Education Exam (ALES) (MNE Circular, 2007). Ministry of Education The General Directorate of Special Education Services has been published a report in January 2013 called "Gifted Individuals Strategy and 


\section{THE CASE OF BEING A TEACHER AT SCIENCE AND ART CENTERS: A PHENOMENOLOGICAL QUANTITATIVE RESEARCH}

Implementation Plan 2013-2017" (MNE 2013). In this report, provide SACs a good corporate status, and equip them with specialist staff are mentioned to be basic objectives. It was also stated that many of SACs have some challenges one of which is finding the qualified staff and some proposals have been made for this problem in this report. The staffs having received postgraduate training and desiring to improve himself in-service training were proposed for working at SACs. It is stated that the teachers having these criterias should be directed to work at the SACs (MNE 2013). From this viewpoint, the selection of teachers for SACs has been redefined by the provision of guidelines issued by the Ministry in 2015 (MNE Guidelines, 2015). The "new" system (2015) is observed to have some differences compared to the "old" system in the selection of teachers for SACs (2007). In what extent this new system is effective to meet the needs of qualified teachers for SACs is the subject of curiosity.

Regarding the role of teachers in the education of gifted individuals, Gross (2005) stated that, the greatest gift to give to a gifted child is a teacher being aware of their abilities, working for their development with pleasure and pleases them rather than make them fear. So the first thing must be done is to determine what the teachers do in gifted education as practitioners of the program created for these children (Davis \& Rimm, 2004).

The teachers' planning of learning-teaching process, their communication with the students and their parents are one of the key issues of gifted education. Thus, what the teachers do in the teaching-learning process for gifted education at SACs is drawing attention. However, the related literature is examined, it can be said that there is a lack of research on "being a teacher in the gifted education" in our country. Although there are several studies related with the educational problems of gifted students (Ataman, 1976; Ekinci, 2002; Gökdere, Ayvacı \& Küçük, 2004; Koçal, Kanar, Ermiş \& Pınar-Kanar, 2009; Tekbaş, 2004), concerning with the teachers' views on gifted students and their education (Kurnaz, Tüybek \& Taşkesen, 2009; Yakmac1-Güzel, 2009), examining the instructional qualities of gifted students' teachers (Gökdere, 2004; Gökdere \& Cepni, 2004; Gökdere, Küçük \& Çepni, 2004; Kontaş, 2009; Kurt, 2006) and examining practices in the SACs (Aktepe \& Aktepe, 2009; Özkan, 2009; Sezginsoy, 2007; Tantay, 2010; Y1ldz, 2010), there is no study examining "Being a teacher in SACs" in various aspects. This study, examined the case of being a teacher at the SACs with various aspects, is thought to contribute positively to the assessment and development of the teaching-learning processes at SACs, and also the results of the study is thought to contribute to decision-makers and managers responsible for the development of these institutions, to be useful in teaching practices for teachers who work in these institutions, to give an opportunity to make self-evaluation to the teachers working or planning to work at these institutions.

\section{Purpose of the Study}

The aim of the research is to examine "the case of being a teacher in SACs"; the selection of the teachers who will work in these institutions, the qualifications of the teachers in these centers, the teachers' planning the teaching process and their interaction skills. For this purpose, it is intended to provide answers to the following questions:

- How is the selection of teachers process assessed at SACs?

- What are the positive and negative aspects of teaching in SACs?

- What kind of instructional activities are the teachers engage in SACs?

- How do the teachers interact (with the students, parents, and the other teachers in the center)?

\section{Method}

\section{Research Model}

The study was carried out with phenomenology design, one of the research designs in line with qualitative research methodology. Phenomenological study identifies the common meaning of a concept or a phenomenon experienced by few individuals (Creswell, 2013: 77). In such a study, researcher concerns with personal experience of the participants, and examines the perceptions of individuals or the meaning they attribute to the events (Baş \& 
Akturan, 2013: 84). In this study, the experienced phenomenon is "being a teacher in SACs, and the teachers are the ones experiencing it. In this study, unbiased phenomenology was used. In accordance with the purpose of study, this kind of phenomenology makes more emphasis on describing the experience of the participants than the researcher's comment (Moustakas, 1994).

\section{Study Group}

The phenomenological study aims to collect first-hand and subjective information. So, its sampling strategy is the purposeful sampling (Baş \& Akturan, 2013: 90). In this regard, to determine the working group of the research, depending on the purposeful sampling strategy, criterion sampling was used, which is used in phenomenological research. The important thing in determining the research group with this sampling method are participants' having real experiences related with the phenomenon and their ability to express this experience clearly (Creswell, 2013). Thus, in accordance with the nature of the subject studied in this research, having five years or longer working experience at SACs and expressing the experience clearly, participating in the research voluntarily are identified as of the criteria to be sample a teacher.

In the phenomenological researches, interviewing with more subjects does not mean getting more information about the targeted phenomenon. Here, the number of individuals interviewed about targeted phenomenon may vary and also it should not be tried to have a higher number of individuals but it should be focused on the quality of the information obtained from subjects (Baş \& Akturan, 2013: 90). In phenomenological researches, creation of a study group from 5 to 25 participants is considered appropriate. (Creswell, 2013: 81). Sandelowski (1995) suggested that in a phenomenological study conducted by experienced research group, the sample size should include a minimum of 6 individuals. By taking these criteria into consideration, 13 teachers working in SACs in three different provinces of Turkey's Eastern Anatolia Region have been selected to collect research data. Because of ethical concerns, the information about SACs where the teachers work has not been clearly stated. Research groups of the study are given in Table 1.

The study group is carefully selected through preliminary interviews among the teachers having those criteria. The information about the teachers' names and the SACs they work in the study group are kept secret by the researchers and are indicated with codes. While coding participants' interview sequences (like T1, T2...) are used.

Table 1. Information about study group

\begin{tabular}{cccc}
\hline The interviewers Code & Gender & Branch & Duration of Employment at SACs \\
\hline T1 & Male & Geography & 9 years \\
T2 & Male & Phy sics & 9 years \\
T3 & Female & History & 10 years \\
T4 & Female & Biology & 5 years \\
T5 & Female & Visual Arts & 5 years \\
T6 & Male & History & 7 years \\
T7 & Female & Geography & 6 years \\
T8 & Male & Physics & 6 years \\
T9 & Male & Math & 6 years \\
T10 & Female & Science and Technology & 5 years \\
T11 & Male & Chemistry & 6 years \\
T12 & Male & Math & 9 years \\
T13 & Male & English & 5 years \\
\hline
\end{tabular}

\section{Data Collection Tool}

In this study, the interview technique which is proposed to be used as a main data collection techniques in the phenomenological study (Creswell, 2013; Patton, 2014, Y1ldirm $\&$ Şimşek, 2013) was used. In the semi-structured interview technique, interview questions are prepared in advance by researchers; but by providing partial flexibility during interview let the created the question to be organizable the discussable (Ekiz, 2015). In this research, semi-structured interview technique was used as it provides flexibility to the researchers. 


\section{THE CASE OF BEING A TEACHER AT SCIENCE AND ART CENTERS: A PHENOMENOLOGICAL QUANTITATIVE RESEARCH}

Semi-structured interview form was developed as a data collection tool to be used in-depth interviews held with the teachers in the study group. A comprehensive instruction was prepared at the beginning of the interview form about the subject and purpose of the study. The pre-application of the interview form was conducted with three teachers working at SACs and the final version was given to the interview form in line with the opinions of the three experts in Educational Sciences. In the Interview Form, there are some questions to reveal the phenomenon of being a teacher at SACs such as "(i) How do you assess the selection of teachers to the SACs? (ii) What are your reasons for choosing to be a teacher at the SACs? (iii) What are the positive and negative aspects of being a teacher at the SACs? (iv) How do you plan the teaching-learning process? What do you do in this process? (v) What do you take into account while arranging the learning environments? (vi) Which assessment and evaluation methods do you use for students? Why? (vii) How is your interaction with the students, parents and other teachers in your centers?". The questions were asked in the order as in the interview form and the data were recorded on a voice recorder. Furthermore, during the interviews, sections emphasized by the teachers were noted. The interviews lasted approximately 40 minutes.

\section{Validity and Reliability}

In the qualitative research, validity means that researchers observe the case as exactly as it is and as neutral as possible (Ylldırm \& Şimşek, 2013: 289). External validity is transferability of the obtained result to the similar groups or settings. Direct quotations are often used by researchers for this purpose (Yıldırım \& Şimşek, 2013). In this regard, to provide the external validity of the study, research findings were defined with direct quotations and the data were reported in detail. Expert review and participants' confirmation are commonly used strategies to increase the internal validity of a study, (Yildirm \& Şimşek, 2013). Therefore, while the experts (a faculty member serving in the Faculty of Education and two instructors done two qualitative studies) observed and gave feedback on the whole research process, the participants analyzed the data and the results obtained from the research and gave feedback to ensure the internal validity of the study. In this way the researcher's subjective assumptions and the misunderstanding of the data were prevented.

The most important measures that the researchers can take for external credibility; is to provide detailed and clear information about both the basic phases of the research, and their own position and approach to the research process. By this way the researcher proves that the results obtained link to the data collected (Yıldırım \& Şimşek, 2013). For this reason, the methodology and procedures are described in detail and attained judgment and interpretations are stated at the a clearly to ensure the external reliability of the research. One of the strategies used to provide internal reliability is to present the collected data directly with a descriptive approach. Namely, the researchers should provide the data obtained through interview to the reader without any comment and interpret them later (Y 1dirm \& Şimşek, 2013). In this regard, interviews recorded with the voice recorder dissolved, obtained data converted into the text and it was analyzed in this form to ensure the internal reliability.

In qualitative research, for the researcher to receive feedback about how accurate his analysis and his data, his making other independent researchers check their data is stated to be important in terms of helping to improve different kinds perspectives (Glesne, 2013; Y1ldirım, 2010). For this reason, a faculty member working in the Faculty of Education and two lecturers made qualitative study were asked to check the findings obtained from the results of the analysis and their confirmation on coding were taken on this issue. At this stage, as re-encoding process is not done, the reconciliation percentage is not calculated but codes were checked completely and to make the final decision, researchers have mutual negotiations about codes considered incorrect. The results of the analysis were given directly without comment of the researchers.

\section{Data Analysis}

Data analysis was conducted by adopting the content analysis approach with QSR NVivo 8 qualitative data analysis software. The main objective of content analysis is to reach 
the concepts and relationships capable of explaining the collected data. For this purpose, first of all it is necessary to conceptualize the collected data, then it should be organized logically according to emerged concepts and accordingly the theme that describes the data must be determined (Y 1ldırım and Şimşek, 2013: 259). In this research, coding method obtained from the data was used, codes and themes were determined by the inductive approach. In phenomenological studies, the researchers are recommended to begin with a detailed analysis and then to pass a wider category with this analysis (Bazeley \& Jackson, 2015: 76). For this reason, to achieve the corresponding phenomenon, coding based content analysis was conducted with an inductive approach. Content analysis was completed after reading the data and by controlling the derived codes.

\section{Findings}

\section{Research Findings Related to the Case of Being a Teacher at SACs}

As a result of analysis of the data, it is observed that teachers' views on the phenomenon of 'being a teacher at SACs' were observed to be grouped under four themes.

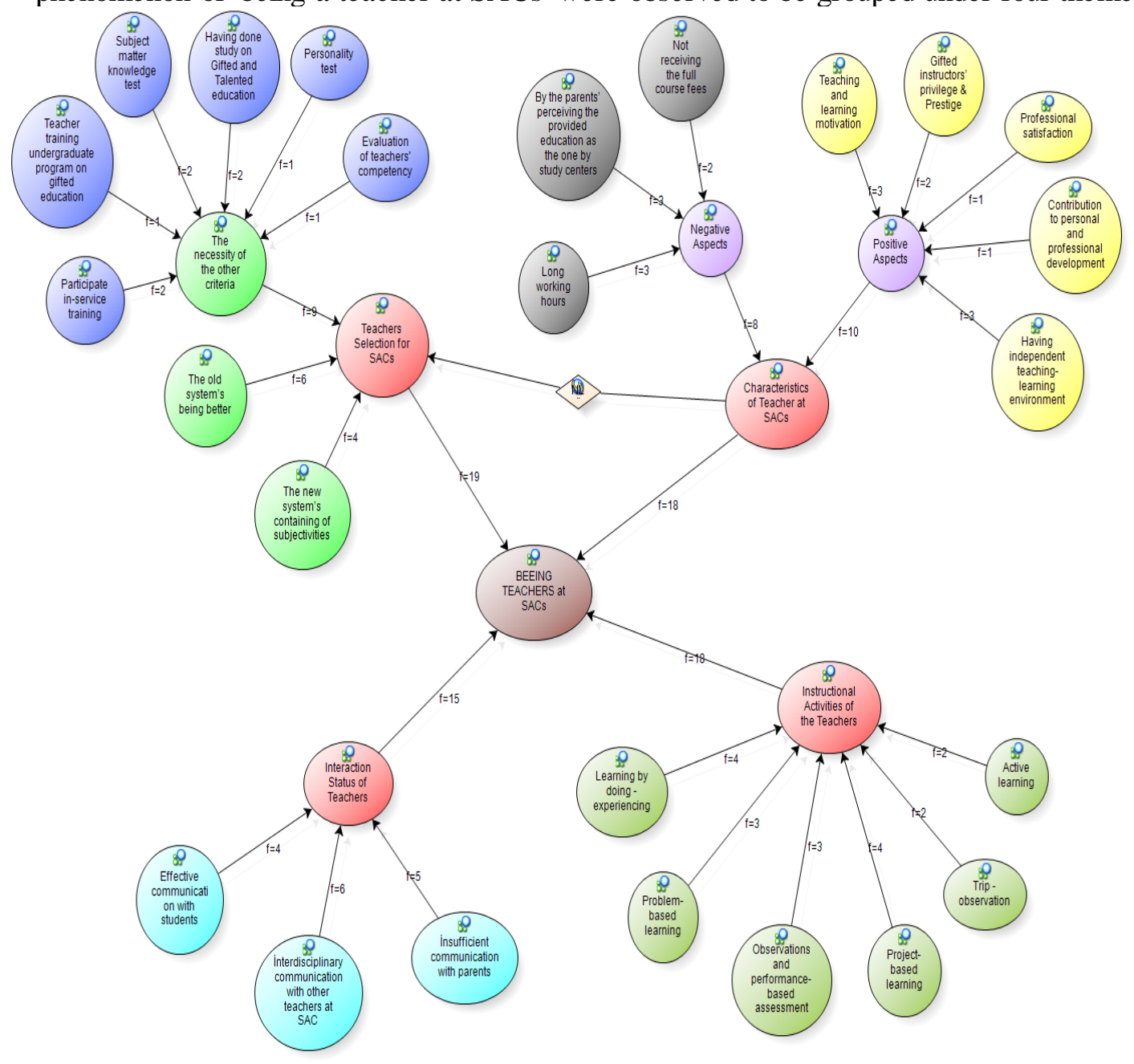

Figure 1. The Model corresponding to the patterns of the themes

As shown in Figure 1, themes consist of "teachers selection for SACs ( $\mathrm{f}=19)$ ", characteristics of teachers at SACs $(\mathrm{f}=18)$ ", "instructional activities of the teachers $(\mathrm{f}=18)$ " and "interactions status of the teachers $(\mathrm{f}=15)$ ". In this model, one-way relationship was 


\section{THE CASE OF BEING A TEACHER AT SCIENCE AND ART CENTERS: A PHENOMENOLOGICAL QUANTITATIVE RESEARCH}

founded from the "The characteristics of teachers at SACs" theme to "selection of teachers for SACs". This relationship is based on the idea of teachers' preferring to work at SACs depending on the positive or negative aspects of being a teacher at SACs and also SACs' choosing teachers among the ones who prefer to work at these centers. The emergence of the research finding that teachers preferred these centers mainly because of the positive aspects of being a teacher at SACs also confirmed this idea. Examples of teachers' statements are as follows:

"At first the SACs was a closed box for us. We did not have an example ahead of us. But in a report about the SAC, it was said that there is more free working environment and in particular there are superior and gifted students so after hearing a work environment where we will work with selected, high quality, interested students attracted us." (T1)

"Despite the concept of working hours is presumed to be very busy, we preferred it. As I thought that the gifted children's education is very important for our country, I preferred this place. So I thought to contribute to this situation. I care about this area." (T2)

By considering the model for the patterns of the themes, each themes were addressed separately and through their models following findings were obtained.

\section{The Findings Related with Selection of Teacher for SACs}

In the interviews, participants were asked to evaluate the selection of teachers to the SACs. After analyzing the data obtained from interviews, the theme of selection of teachers for SACs emerged by the evaluation of old (2007), the new (2015) and other systems. Figure 2 shows the model related with this theme.

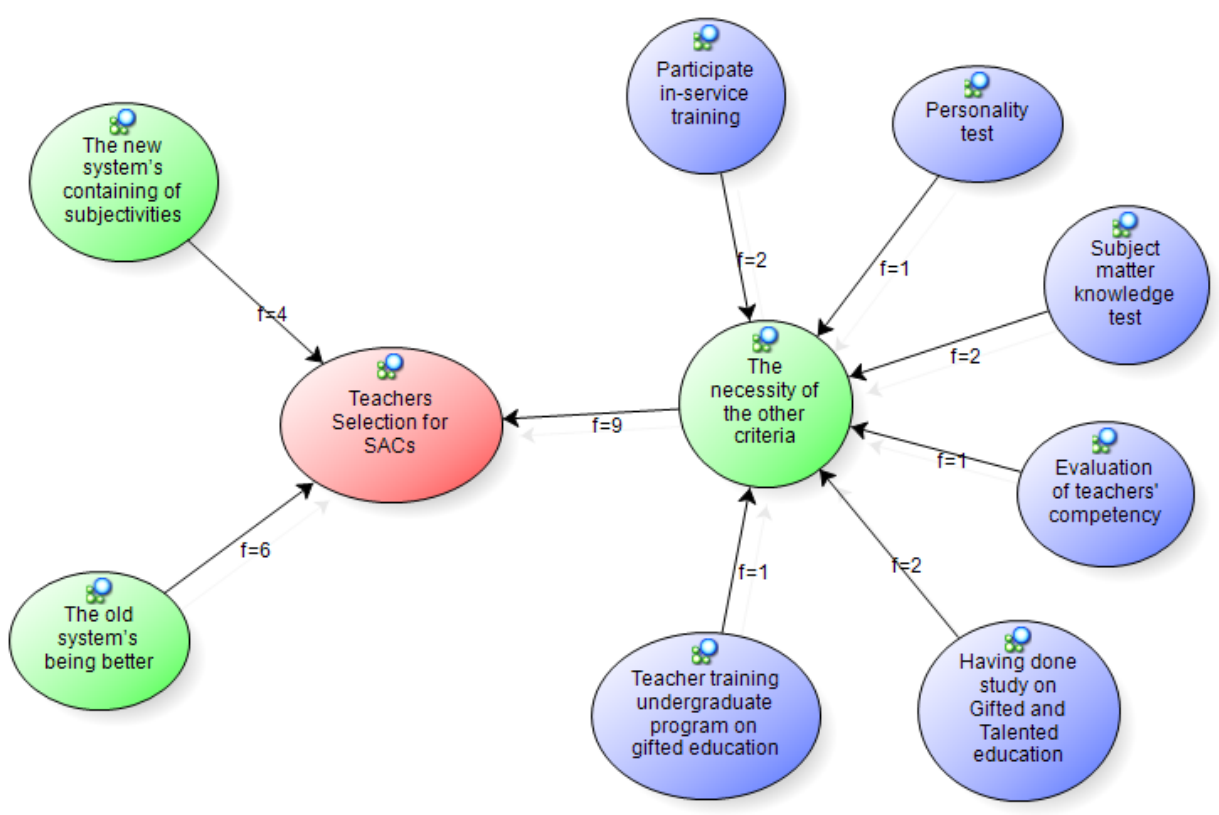

Figure 2. The model corresponding to the selection of teacher for SACs

As shown in the Figure 2, the theme of the selection of teachers for SACs ( $f=19)$ consist of "the new system's containing of subjectivities $(\mathrm{f}=4)$ " and "the old system's being better $(\mathrm{f}=6)$ " and "the necessity of the other criteria $(\mathrm{f}=9)$ " subthemes. According to the theme of the selection of teachers for SACs, teachers were determined to compare old (2007) and new 
(2015) systems and to emphasize that there should also be other criteria. Sample sentences of the interviewed teachers to support these findings are listed below.

\begin{abstract}
"In the past, first we had a written exam and then we received a month-long project evaluation seminar, and finally there was an interview at the end of seminar. And I think this system is very useful. At that time, having made at least a written exam is always beneficial in terms of determining the qualified teachers. Making the teachers having a master's degree and Ph.D. subject to a written exam will reveal the decisiveness of the process. I think the previous system was better. I do not think the assessment at the current system ensures the equality. In one place, while Teacher $X$ is given more than one achievement certificate for his pre-assessment scores, unfortunately, that's not happening in another city or the awarding system such as giving commendation, certificate of appreciation, certificate of achievement is not applied objectively and fairly and of course those things effects the scores differently. Consequently, this situation brings inequality in the competition. I think that a written exam will always be beneficial for the institutions." (T1)
\end{abstract}

"I do not think either of these two systems are enough. I just find the preliminary criteria of the new system acceptable. I do not think following oral interviews are conducted quite adequately. If you are looking for teachers for gifted students at SACs, there should be no the incident called torpedo among people. Because these institutions need qualified teachers to develop students' skills." (T9)

In line with these statements, it is found that teachers think that the old system is better in its assessment criteria and the validity concerning with the selection of teachers for SACs, and they could not adopt the new system as it contains subjective evaluation criteria. In addition to criteria for selection of teachers for SACs in the old and new systems, teachers' statements regarding the requirement for further criteria are listed below.

\begin{abstract}
"First of all, teachers must undergo a training, not just as a general education but it must concern about their own branch and especially training of gifted children. For example, how Gifted children are trained in Physics. After they have such a training, they may be subjected to an examination. Of course, this may not be the only criterion, but when the percentage is considered, the highest rate needs to be given this training."
\end{abstract} (T8).

\begin{abstract}
"First of all, teachers should be very good at their own branches and this difference should be considered when selecting the teachers. Then, the teachers' knowledge of methodology and teaching skills must be very well and the selecting process must be handled in parallel with these two. Apart from these, I think that the departments should be established at universities which can provide training to gifted students. For example, the department of Teaching Mathematics, Chemistry, Geography, Biology to the gifted students. I think, if the teachers were trained like this way for these institutions, everything would be better." (T13)
\end{abstract}

\footnotetext{
"Requirement of doing an academic work in the field of gifted education could be added to the preliminary evaluation criteria. For example, a Mathematics teacher is supposed to have an academic study on Mathematics education of gifted students." (T12)
}

The teachers' statements about the selection of teachers for SACs, indicate that teachers are of the opinion that the requirement such as "evaluation of teachers' competency $(\mathrm{f}=1)$ ", "participate in-service training ( $\mathrm{f}=2)$ ", "personality test $(\mathrm{f}=1)$ ", "subject matter knowledge test $(\mathrm{f}=2)$ ", "teacher training undergraduate program on gifted education $(\mathrm{f}=1)$ ", and "Having done study/research on gifted and talented education $(\mathrm{f}=2)$ " should be added to the current system.

\title{
The Findings Related with the Positive / Negative Aspects of Being a Teacher at SACs
}

Depending on the theme of the characteristics of the teacher at SACs $(\mathrm{f}=18)$, teachers have described the being a teacher at SACs within the scope of the positive and negative aspects. Figure 3 shows the model related with this theme. 


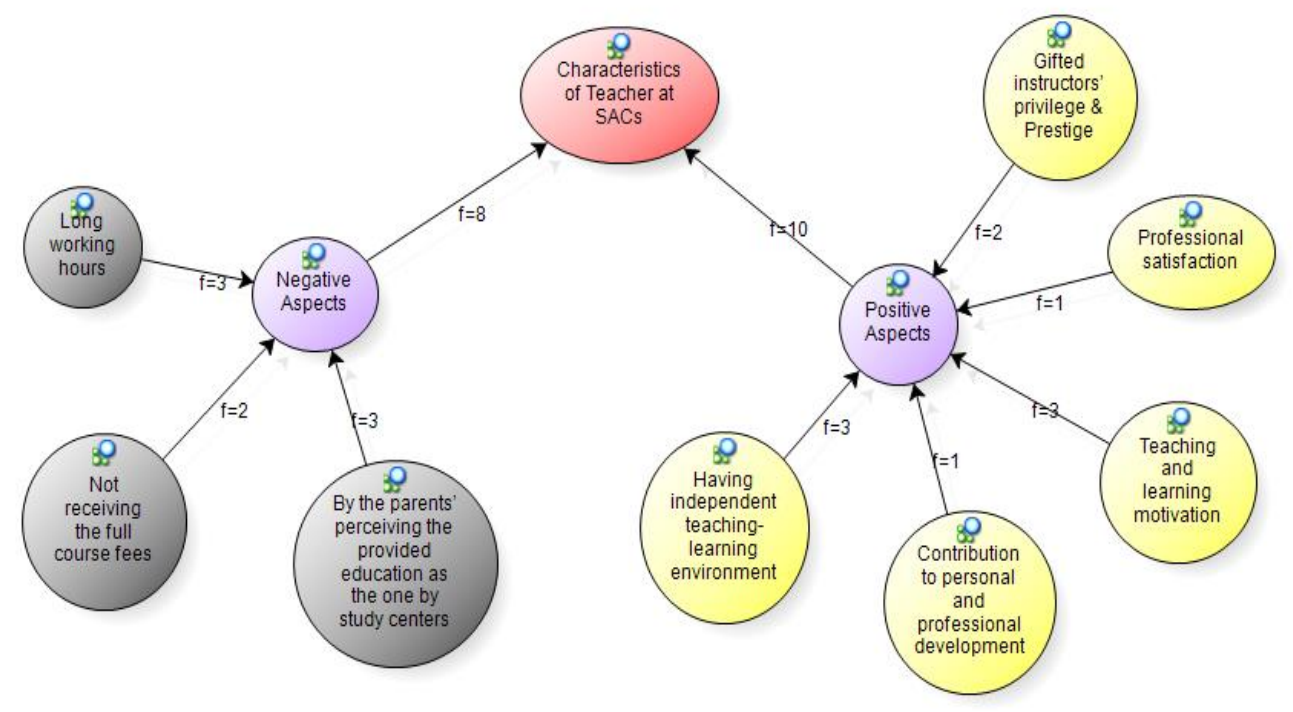

Figure 3. The model corresponding to the characteristics of being a teacher at SACs

The teachers' sample statements related the positive aspects $(\mathrm{f}=10)$ of being a teacher at SACs are as follows:

\begin{abstract}
"There is an independent working environment at SACs. There is not a classical curriculum. Especially teachers do not have to prepare some restricting documents for the written-oral exams, performance tasks or other counselling and club files as in other schools. In this sense, I can say that it has more free working environment and it is more comfortable. In this regard, providing a higher level of training to these individuals while being open to professional innovations and improving ourselves and also witnessing students' reaching much better position bring us professional satisfaction." (T1)
\end{abstract}

\begin{abstract}
"SACs use project-based training. In these centers, teachers and students to come together and at the end of the training process they produce a product within the project creating training. As I think that this way is more efficient, as a teacher it satisfies me more. I feel myself privileged in this institution. it is a prestigious institution. I work with gifted students. I think working with these students is a great pleasure and a great source of pride. Because gifted students may be a CEO, a president, a member working on a special task in the future. As I believe that my students will provide great service not only to my country, but also to the world my motivation is always high. That is why I believe that working at SAC is a prestigious job." (T13)
\end{abstract}

The teachers' statements about the positive aspects of being a teacher at SACs are as follows: education of the gifted students is being privileged / prestigious $(f=2)$, having independent teaching-learning environment (mainly project-based) ( $\mathrm{f}=3$ ), contribution to personal and professional development $(\mathrm{f}=1)$, to teaching and learning motivation $(\mathrm{f}=3)$, and to the professional satisfaction $(\mathrm{f}=1)$.

The teachers' sample statements about negative aspects $(\mathrm{f}=8)$ of being a teacher at SACs are follows:

"We have a shift system that does not exist in other schools. We have to be at school at 8:00 in the morning and have to stay at school until 6:30 to 7:00 in the evening and this $i s$ really tiring. It also does not contribute anything to personal rights. the personal rights need to be improved. For example, although we work intensely nowadays, many of our friends cannot receive the full course fee, which is another additional problem. if there was a working system based on full yearlfull-time principle, teachers would 
provide all the contributions they could without thinking the concept of additional courses and working overtime, but now, unfortunately, we have such a problem." (T1)

"Actually, there is a problem caused by parents at SACs. The parents expect us to provide courses for both YGS-LYS and TEOG exams, but there is no such course in these institutions. When we explain this to the parents, they do not want to send their children to our institution. The parents direct their students to the private teaching institutions or to take private lessons. This problem must be solved and this is something that can be done through the ministry. I believe that such problems can be resolved if the necessary sensitivity is shown to the SACs." (T5)

As it can be understood from the teachers' statements, the long working hours $(f=3)$, not receiving the full course fees $(\mathrm{f}=2)$, parents' perceiving the training at this centers like the one in study centers ( $\mathrm{f}=3$ ) are thought to be negative aspects of being a teacher at SACs. However, analysis of results indicates that teachers refer less to the negative aspects of being a teacher at SACs than their positive ones.

\section{The Findings Related to the Teachers' Instructional Activities}

The teachers interviewed were asked to explain how they plan teaching-learning process and what they do in this process. The theme of teachers' instructional activities emerged with the analysis of the data. Figure 4 shows the model related with this theme.

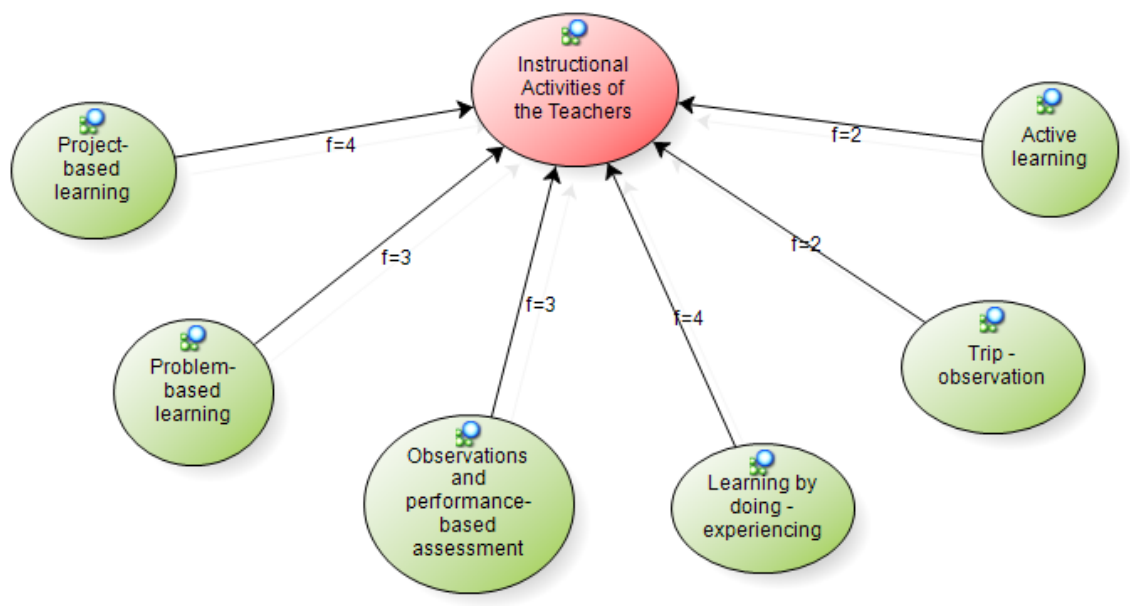

Figure 4. The Model corresponding to the teachers' instructional activities

As shown in figure 4 , the teachers perform the instructional activities $(\mathrm{f}=18)$ such as learning by doing-experiencing $(\mathrm{f}=4)$, project based learning $(\mathrm{f}=4)$, trip-observation $(\mathrm{f}=2)$, active learning ( $\mathrm{f}=2$ ) and problem-based learning $(\mathrm{f}=3)$. This is also supported by the sample statements below.

"I'm trying to follow the exact curriculum which the children have in their own schools. By ignoring the curriculum, we try to arrange more interesting and up to date activities appropriate to the learning by doing model. And especially during these activities, we are trying to make them create models based on their handicrafts and demonstrate new features of some existing materials related to that topic. While doing these activities, we are also trying to use audiovisual tools effectively. Consequently, I can say that by diversifying and differentiating activities, I try hard to make them attractive to the children." (T1)

"We do not have an exact schedule. The teachers create their own plans. For each lesson special activities are organized. After planning these activities, I try to attract the attention of the students in the classroom. There are extracurricular activities organized by teachers. Even If I do not organize such activities, I adapted them to my classes. For 


\section{THE CASE OF BEING A TEACHER AT SCIENCE AND ART CENTERS: A PHENOMENOLOGICAL QUANTITATIVE RESEARCH}

example, bird observation was made two weeks ago. There are a lot of birds where I live. This activity was planned by our science teacher. During this activity I organize a game based learning activity to help the students learn the English corresponds of the names of the birds. During the bird watching activity, I asked them English corresponds of the names of the birds one by one. Of course, this was more permanent way of learning." (T13)

In addition to this, the statements about how they do measurement and evaluation are emphasized under the subthemes of observation and performance based assessment $(\mathrm{f}=3)$. This is also supported by the sample statements below.

"We do lesson evaluations at the end of the classes and especially there are evaluations of performance and monitoring. And we share them with the parents." (T5)

"Obviously, we're doing assessment and evaluation orally in the form of giving feedback to the students. There is no oral-written exam, multiple choice test or a report card in this centers. Here, we're trying not to intimidate the kids with techniques like grading. We try to make hay while the sun shines." (T6)

"We observe more, we care the performance or we let them to fill in the blank in the concept maps and in this regard we do the assessment." (T7)

The statements of teachers revealed that there is no a grading system in assessment and evaluation process and the assessments are generally done based on observation and performance.

\section{The Findings Related to the Teachers' Inte raction Situations}

During the interviews, the participants were asked to explain how they communicate with other stakeholders at the centers. As a result of the analysis the theme of teachers' interaction situations emerged. The model concerning this theme is shown in Figure 5.

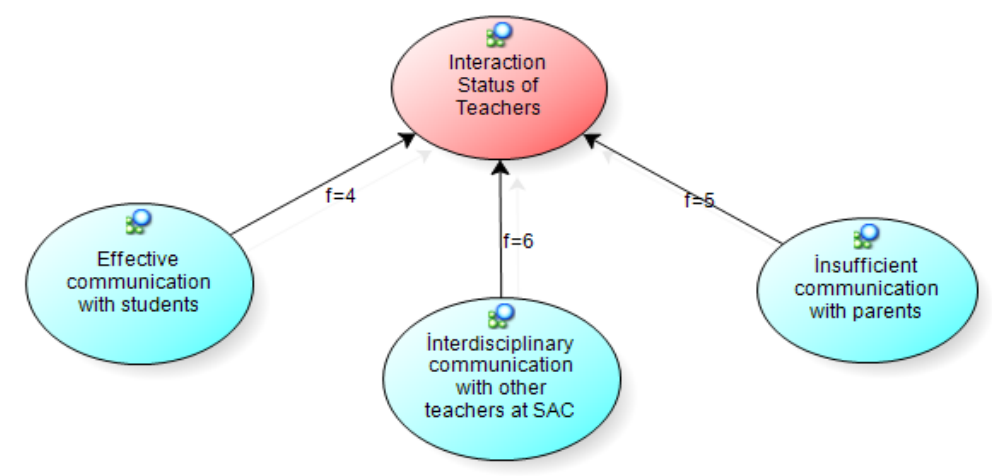

Figure 5. The model corresponding to the teachers' interaction situations

Teachers are reported to have interaction with students, with other teachers at SACs and parents under the theme of interaction status of teachers $(\mathrm{f}=15)$.

Some sample statements of teachers' views on the state of their interaction with students $(\mathrm{f}=4)$ are given below.

"I think that teachers' relationship with their students is quite well. That is to say, as the number of groups are few, students are aware of being cared and their differences are valued. Here they feel more valued." (T10) 
"I think that the teachers' communication with their students is good, and also the success of these centers result from the positive communication established by teachers and students." (T2)

In line with the statements of the teachers, it can be inferred that in general teachers have an effective communication with their students. Some sample statements of teachers' views on the state of their interaction with the other teachers $(\mathrm{f}=6)$ at SACs are given below.

\begin{abstract}
"Our relationship with our colleagues is really good. Especially just because of our field (Mathematics) we cooperate with Physics department. For example, Physics department says us that they will cover the following topics in their lesson, but before starting they need some mathematical information so they want help from us with this. We gladly provide this support and we also contribute to the Physics lesson. So when there are shortcomings, we try to overcome them. Sometimes we interact with the English department. For example, while I was showing Teog exam of New Zealand to the students, I came across some ambiguity in the questions. I immediately asked to the English teacher, he made the necessary explanations and helped us to continue our lesson. We also cooperate with our art and computer teachers, especially when we participate in the projects, they do our posters in a dedicated way." (T9)
\end{abstract}

"The studies conducted at SACs are usually done in interdisciplinary way. They take place in the form of teamwork. For example, there are studies combining Science and English. The study is started by English teacher, but he consults the science teacher for the rest of the study. The collaborative works like these are done at SACs. We have no troubles in this issue, I can say that the relationship between the teachers is strong." (T13)

In the light of the teacher's statements, it was determined that teachers interact with each other at SACs when it comes to interdisciplinary teaching. The sample statements of teachers' views on the state of their interaction with the parents $(\mathrm{f}=5)$ are as follows:

"We do not actually work together with the parents. For parents we are closed off. This makes it difficult to have a positive relationship with the parents." (T7)

"To be honest, there are many complaints from the parents about some issues. For example, there are some complaints on teachers' frequently change or not providing adequate exam preparation programs. Because of these, they are criticizing the institution. For these reasons they often do not participate in the meetings. This cause a breakdown in communication with the parents." (T13)

These statements reveals that the level of teachers' communication with the parents is inadequate at SACs.

\title{
Discussion and Conclusions
}

This study examined the case of being a teacher at SACs which play an active role in the education of gifted children showed that the case of "Being a teacher at SACs" composed of " The selection of teachers for SACs ", "The characteristics of being a teacher at SACs", "Instructional activities of the teachers" and "Interaction situations of teachers".

In this study, it was concluded that teachers find the system in 2007 (old system) better in general in terms of the evaluation criteria and validity of the selection of teachers for SACs, and they cannot adopt the system in 2015 (new system) because it contains subjective evaluation criteria. It is found that the teachers consider that teachers' being taken into inservice training and preparing project are positive aspects of the old system but prioritizing the oral exam in the new system were found to be considered negatively. That the teachers' lack of knowledge about the education provided to the gifted children and the impacts of this training to meet their academic and emotional needs is highlighted in several studies (Gross, 1994; Sak, 2011). Indeed, in the study carried out by Ôzer Keskin, Keskin Samanc1 and Aydin (2013), when the participants' views about the selection of teachers for SACs are analyzed, their considering themselves as "partially sufficient" in the teacher selection 


\section{THE CASE OF BEING A TEACHER AT SCIENCE AND ART CENTERS: A PHENOMENOLOGICAL QUANTITATIVE RESEARCH}

process is a remarkable result. The results of the study by Sezginsoy (2007) suggest that the problems of education and training process are related with teachers' not taking adequate inservice teacher trainings and so their not knowing what to do for developing educational applications for the gifted students. According to the results of the research done by Şahin and Levent (2015), it was stated that the teachers demonstrate a lack of knowledge of the subject matter and they need in-service training. In this study, it is also stated that teachers' competencies in the area of gifted individuals and their education can be improved by providing them pre-service training, in-service training or postgraduate education. The considerations stated above support this research resulting that the old system is better.

In this study, it was found that in addition to the requirements for the teacher selection for SACs in the old and the new systems, the criteria such as "Assessment the teachers' competency", "Receiving in-service training", "Being subjected to a personality test", "Subject matter knowledge test", "A branch at university as the department of gifted individuals teaching", "Making studies on gifted education as a preliminary evaluation criteria" must be included in the teacher selection system. There are research findings available regarding the teachers not having enough knowledge in the field of gifted education have some misconceptions related with the academic needs or social and emotional development of these students (Bain, Choate \& Bliss, 2006). For this reason, considering the talents, social and emotional needs of the gifted students, it can be said that the teachers who will work in these institutions must be trained for the gifted students. In fact, that the individuals who graduated from the Department of Gifted Education work at the SACs is reported to fulfill the mission of these institutions (MNE, 2010a). In many studies, teachers trained for gifted children have been found to be able to increase their proficiency in developing instructional strategies in the education of gifted students (Johnson, Vickers \& Price, 1995; Reis \& Westberg, 1994). These findings indicate the need for other additional criteria for the selection of teachers which is an important area of gifted education.

The result of this research has been identified some positive aspects of being a teacher at SACs such as being a gifted instructor is privileged / prestigious, having an independent teaching-learning environment (mainly project-based activities), personal and professional development, contributing to the teaching and learning motivation and to the professional satisfaction. The students studying at the SACs receive project-based education depending on their interests and talents beside their formal education (MNE, 2010b). Creating and developing project are on the basis of the activities held at the SACs. At SACs, as a teaching model, instead of teacher teach model, students learn in a project set by themselves during which related topic is learnt by applications of their own solutions rather than teachers teaching to the students (Davasligil et al, 2004). Consequently, there is not a certain curriculum at SACs and the teaching-learning activities are formed in accordance with the the students' needs. In the light of the research findings, it is found that teachers appreciate this situation as it ensure the formation of aspecial teaching-learning environment. Furthermore, the teachers consider being a teacher of gifted students as privileged and prestigious because of skills and characteristics required. Meanwhile, it is found that capabilities of the gifted students and efforts to use these skills in the teaching-learning process to meet their cognitive and affective needs contribute to the teachers' teachinglearning motivation and their personal and professional development. The statements that the teachers' witnessing improvements in their own and the students' capabilities and their awareness of the importance of these talented students' contribution to society is found to bring them professional satisfaction.

The results of this research identified some negative aspects of being a teacher at SACs such as the long working hours, the not paid for additional classes, the parents' perceiving the education given like in the study center. In the study done by Özer Keskin, Keskin Samanc1 and Aydin (2013), teachers are said to have problems with working conditions and hours as there is no clear employee rights for SACs as well. Accordingly, it is stated that there is no standard for centers and different applications are available. Another functioning problem is thought to be caused by the parents not having enough knowledge about the role and responsibilities of the SACs. This situation is stated to cause parents suffering from 
exam anxiety to perceive project works done at this centers negatively. The problems mentioned in this study also emerged in the findings and it was found that teachers consider them as the negative aspects of being a teacher at SACs. However, most teachers were observed to have views on positive aspects of being a teacher at SACs.

In this study, it was concluded that the teachers at SACs use instructional activities such as learning by doing, project based learning, field trips, active learning and problem-based learning. In the study done by Sezginsoy (2007), it is concluded that teachers of gifted students at SACs encourage students to generate new ideas, allow the students to express themselves in class, make students relate what they learnt in their life, make students learn topics in depth, teach subjects through exploration and questioning, and direct the students project works etc. In the study done by Ylmaz-Atik (2007), it is found that methods such as "learning through analysis", "learning through discovery" and "learning with experiments" are the preferred methods in the mathematics lessons at SACs. In the study done by Kazu and Senol (2011), it is stated that teachers at SACs always use "Observation" and they often use "Project-based learning" and "problem-based learning" for education of gifted students. In the study done by Yildiz (2010), it is concluded that according to the teachers, students and parents, SACs contribute to the students' problem-solving skills, group work skills, creative thinking skills and to their working with scientific method. Consequently, it is seen that these studies support the results of this study.

Additionally, it was observed that there is no a grading system in the process of assessment and evaluation and in general observation and performance-based assessment is done at SACs. The assessment and evaluation process at SACs aims to support the learning process, to realize level of achievements related to the competency domains, to guide students to the disciplines or sub-disciplines suitable for their interests - abilities, and to monitor the students' all types of developments. The assessment and evaluation process in SACs, does not depend on grading. Apart from their usage for evaluation of the education process, the measurement and assessment tools applied to evaluate the education process of gifted children are used for diagnosing and exploring the children's areas of interests/abilities, and for making plans which ensure the development of the areas of ability. For this purpose, it is stated that the assessment and evaluation process of these institutions includes applications such as performance-based assessment, authentic assessment, portfolio assessment and dynamic assessment (MNE, 2014). The results of the research revealed that within these applications, teachers often use the performance-based assessment.

In this study it was concluded that the teachers communicate effectively with their students at SACs. In the study done by Kazu and Şenol (2012), it was concluded that in the gifted students' education, the smallest amount of problems is related with communication. In the study done by Tantay (2010), it was concluded that all of the teachers of gifted students can understand and communicate well with them and this supports the results of our study. In this study, it was determined that on the basis of interdisciplinary teaching, teachers interact with other teachers at SAC. Considering the purpose of establishment of SACs and the skills possessed by the gifted students, the gifted students' researching-questioning, discussing and product development skills should be supported by creating project-based learning environments with an interdisciplinary approach (Özer Keskin, Keskin Samanc1 \& Aydin 2013). The data obtained in this study indicates that based on the interdisciplinary learning approach, the teachers interact with other teachers in the center to create this type of learning environment.

The teachers' interaction with parents at the SACs was found to be inadequate. However, in the instruction of Science and Art Centers, it is stated that teachers are responsible for their students' interactions with their families; with the environment; and with the formal educational institutions they attend to make the education provided in SACs be effective (MNE 2007). For this, the research finding that the teachers lack of communication with parents shows that the teachers at SACs are deficient in fulfilling their duties in this regard. 


\section{THE CASE OF BEING A TEACHER AT SCIENCE AND ART CENTERS: A PHENOMENOLOGICAL QUANTITATIVE RESEARCH}

Based on the results of the research, the following suggestions can be made:

- The selection of teachers for SACs should be done in accordance with the criteria established objectively. For the selection of teachers at SACs the following criteria can be established; competence, taken in-service training on the gifted education, field test, to be done studies on gifted education

- The teachers should be periodically given in-service training in the education of gifted students. The contents of in-service training seminar should be prepared by considering the needs of teachers at the centers. In these trainings the application-oriented activities can be included to make teachers better in project based learning. Within the implementation and evaluation process of the in-service training program, cooperation with universities can be done and the support can be obtained from experts, organizations and institutions on giftedness.

- The undergraduate courses of the department of gifted children education include the major area courses (general), vocational courses (introduction to teaching profession, teaching practices) and elective courses. At universities, the undergraduate program for gifted education should be given separately for each branch. By this way, universities can provide gifted education training on the basis of the students' major areas (branches).

- The information about the characteristics and training of the gifted students may be given in the Education Faculty of the Universities. In this context, additional activities that give enough background information and raise awareness on gifted education may be done for the prospective teachers of the faculty of education.

- Some rearrangements and revisions can be done for the issues such as personal rights, completion of additional courses and working hours of teachers at SACs. Making teacher forget the idea of working for the additional courses and ignore the length of the working hours and do their best for the education of gifted students can be achieved by creating a working system based on the full-day, full-year principle.

- The parents should be informed about the roles and responsibilities of the SACs. MNE may organize introductory seminars about the SACs especially for the parents.

- At SACs, some works strengthen the teachers' interaction and collaboration with parents should be done.

The suggestions for the researchers in the line with this study are as follows:

- Researches concerning with the professional development and competencies of the teachers in SACs can be done.

- Researches concerning with in what way the in-service training activities improve the teachers' performance in general or for branches can be done.

\section{References}

Aktepe, V. \& Aktepe, L. (2009). Teaching method using science and technology education on students' aspects: The example of Kırşehir BİLSEM. Ahi Evran University Journal of Kırşehir Faculty of Education, 10 (1), 69-80.

Ataman, A. (1976). Educational problems of gifted students a research in Ankara science high school. Unpublished doctoral dissertation, University of Ankara, Faculty of Education, Ankara.

Ataman, A. (1998). Gifted and Talented. Anadolu University, Open University Press.

Bain, S. K., Choate, S. M. \& Bliss, S. L. (2006). Perceptions of developmental, social, and emotional issues in giftedness: Are they realistic? Roeper Review, 29, 41-48.

Baş, T. \& Akturan U. (2013). Qualitative research methods (2 ${ }^{\text {nd }}$ edition). Ankara: Seçkin.

Bazeley, P. \& Jackson, K. (2015). Qualitative Data Analysis with NVivo (Translation of the $2^{\text {nd }}$ edition) (Trans. A. Bakla \& S. B. Demir). Ankara: An1.

Creswell, J. W. (2013). Qualitative inquiry \& research design. Choosing among five approaches (Translation from 3th Edt.) (Trans. Edt. M. Bütün \& S. B. Demir). Ankara: Siyasal.

Davasligil, Ü., Uzun, M., Çeki, E., Köse, M. A., Çapkan, N. \& Şirin, M. R. (2004). Due diligence commission's preliminary report for Gifted children. Istanbul: Çocuk Vakfi.

Davis, G. \& Rimm, S. (2004). Education of the gifted and talented (5 $5^{\text {th }}$ edition). Boston: Allyn and Bacon. 
Ekinci, A. (2002). Evaluation of teachers' views concerning the availability level of elementary schools for gifted children's education. Unpublished master's thesis, Dicle University Institute of Social Sciences, Diyarbakir.

Ekiz, D. (2015). Scientific Research Methods (4 ${ }^{\text {th }}$ edition). Ankara: An1.

Glesne, C. (2013). Becoming qualitative research (Trans. Ed. A. Ersoy \& P. Yalçınoğlu) (3 ${ }^{\text {rd }}$ edition). Ankara: An1.

Gökdere, M. \& Çepni. S. (2004). A study on the assessment of the in-service needs of the science teachers of gifted students: a case for science art center. Journal of Gazi University Faculty of Education, 24(2), 1-14.

Gökdere, M. (2004). A study of developing a model for the eduction of science teachers of gifted children. Unpublished $\mathrm{PhD}$ thesis, Karadeniz Technical University, Institute of Science and Technology, Trabzon.

Gökdere, M., Ayvacı, H. S. \& Küçük, M. (2004). The fundamental problems of the gifted children. Contemporary Education Journal of Education, 29 (313), 23-32.

Gökdere, M., Küçük, M. \& Çepni, S. (2004). A study on the use of technology in education gifted students in science education: Science and Art Centers sample. The Turkish Online Journal of Educational Technology - TOJET, 3(2), 149-157.

Gross, M. U. M. (1994). Changing teacher attitudes to gifted students through in-service training. Gifted and Talented International, 9(1), 15-21.

Gross, M. U. M. (2005). Exceptionally gifted children. London and New York: Routledge Falmer.

Hebert, T. P. \& Neumeister, K. L. S. (2000). University mentors in the elementary classroom: supporting the intellectual, motivational, and emotional needs of high-ability students. Journal for the education of the gifted, 24, 122-148.

Johnson, A. B., Vickers, L. \& Price, R. (1995). Teaching gifted children: A summer institute for regular classroom teacher. Education, 105(2), 193-200.

Kazu, I. Y. \& Şenol, C. (2011). Examination of teaching methods used in science and art centers. Educational Science \& Practice, 10(19), 1-24.

Kazu, İ. Y. \& Şenol, C. (2012). Views of teachers about gifted curriculum (case of SAC). Einternational Journal of Educational Research, 3(2), 13-35.

Koçal, Z. D., Kanar, E., Ermiş, S. \& Pınar-Kanar, K. (2009). Basic Needs of Gifted Students at the Science and Art Center: Amasya Sample. II. National Congress for New Expansions for Gifted / 25-27 March 2009, Anadolu University, Eskişehir.

Kontaş, H. (2009). The effectiveness of the in-service training program developed on the basis of the needs of the teachers of science and art centers in the area of curriculum development. Unpublished Doctoral Thesis, Hacettepe University, Institute of Social Sciences Department of Education Sciences, Department of Curriculum and Instruction, Ankara.

Kurnaz, A., Tüybek, C. \& Taşkesen, Ü. S. (2009). The views and practices of the classroom teachers related to gifted students. II. National Congress for New Expansions for Gifted / 25-27 March 2009, Anadolu University, Eskişehir.

Kurt, L. (2006). To pick out the problems which are faced during supplementary education by the science teacher of science and art center. Unpublished Master thesis, Karadeniz Teknik University, Department of Secondary School Science and Mathematics Education, Trabzon.

Levent, F. (2011). Handbook on the rights of the gifted child, for parents and teachers. İstanbul: Child Foundation.

MNE Circular (2007). Selection of teachers to science and art centers (http://www.memurlar.net/common/news/documents/96253/genelge_87.pdf downloaded from the address.)

MNE Guide (2015). The Guide for Teacher Selection and Nomination to Science and Art Centers (http://orgm.MNE.gov.tr/MNE_iys_dosyalar/2015_09/18044554_blsematamaklavuzu._pdf downloaded from the address.)

MNE. (2007). Directive of Science and Art Centers.

MNE. (2010a). T. C. Head of the Internal Audit Unit of the Ministry of Education, Process of Science and Arts Centers (Education of Gifted Individuals) Internal Audit Report, 2010/14, Ankara.

MNE. (2010b). Gifted/Talented Education Workshop. Ankara: MNE, General Directorate for Special Education Guidance and Counseling Services. 


\section{THE CASE OF BEING A TEACHER AT SCIENCE AND ART CENTERS: A PHENOMENOLOGICAL QUANTITATIVE RESEARCH}

MNE. (2013). T. C. Ministry of Education Directorate General of Special Education and Guidance Services, Strategy and Implementation Plan for Gifted Individuals 2013-2017, Ankara.

MNE. (2014). The Draft framework of Education Program for Special Talented Individuals, Ankara.

MNE. (2015). Regulations for Science and art centers.

Moustakas, C. (1994). Phenomenological research methods. Thousand Oaks, California: Sage.

Özer Keskin, M., Keskin Samanc1, N. \& Aydın, S. (2013). Science and art centers: Current status, problems, and solution proposals. Journal of Gifted Education Research, 1(2), 78-96.

Özkan, D. (2009). The organizational effectiveness of science and art centers in accordance with the opinions of managers, teachers, parents and students. Unpublished Master thesis, Ankara University Institute of Education Sciences, Ankara.

Patton, M. Q. (2014). Qualitative research \& evaluation methods (Translation from $3^{\text {th }}$ edition) (Trans. Ed. M. Bütün \& S. B. Demir). Ankara: PegemA.

Reis, S. M. \& Westberg, K. L. (1994). The Impact of staff development on teachers' ability to modify curriculum for gifted and talented students 1. Gifted Child Quarterly, 38(3), 127-135.

Şahin, F. \& Levent, F. (2015). Examining the methods and strategies which classroom teachers use in the education of gifted students. The Online Journal of New Horizons in Education, 3(5), 73-82.

Sak, U. (2011). An Overview and Social Validity of the Education Programs for Talented Students Model (EPTS). Education and Science, 36(161), 1-17.

Sandelowski, M. (1995). Sample size in qualitative research. Research in Nursing and Health, 18(2), 179-183. doi: 10.1002/nur.4770180211

Sezginsoy, B. (2007). An evaluatıon on sclence-art center ımplementatıon. Unpublished Master thesis, Balkesir University Institute of Social Sciences Department Of Education Sciences, Balıkesir.

Sicak, A. \& Akkaş, E. (2013). The development of the attitude scale for Gifted students in Science and Art Center (SAC). Journal of Gifted Education Research, 1(2), 136-145.

Summak, M. S. \& Çelik-Şahin, Ç. (2014). Defining standards for principal, teacher competencies and instructional objectives in science and arts centers. Journal of Gifted Education Research, 2(2), 86-104.

Tantay, Ş. (2010). Examining schools and centers for educating the gifted and talented. Unpublished Master thesis, Maltepe University Institute of Social Sciences Department Of Education Sciences, İstanbul.

Tekbaş, D. (2004). An analysis of a sample incident on the enriched programme applied to a gifted child in a mainstreaming environment and a research on the efficiency of the programme. Unpublished Master thesis, Gazi University Institute of Education Sciences, Department of Elementary Education, Ankara.

Yakmac1-Güzel, B. (2009). The Turkish teachers' views on the education of gifted and talented. II. National Congress of the New Expansions for Gifted / 25-27 March 2009, Anadolu University, Eskişehir.

Ylldırım, A. \& Şimşek, H. (2013). Qualitative research methods in social sciences (9 $9^{\text {th }}$ Edition). Ankara: Seçkin.

Ylldırm, K. (2010). Raising the quality in qualitative research. Elementary Education Online, 9(1), 79-92.

Yildı, H. (2010). A case study on the arts and science centers which are a model for the education of gifted and talented children. Unpublished Master thesis, Gazi University Institute of Education Sciences Department of Educational Sciences, Ankara.

Yllmaz-Atik, SS. (2007). The evaluation of the methods applied on gifted students in elemetary school. Unpublished Master thesis, Dokuz Eylül University Institute of Education Sciences, İzmir. 